\title{
STRUCTURAL CROSS SECTIONS THROUGH THE CORINTH-PATRAS DETACHMENT FAULT-SYSTEM IN NORTHERN PELOPONNESUS (AEGEAN ARC, GREECE)
}

\author{
N. FLOTTÉ ${ }^{1} \&$ D. SOREL ${ }^{1}$
}

\begin{abstract}
Structural mapping in northern Peloponnesus reveals the emergence of an E-W striking, more than $70 \mathrm{~km}$ long, low angle detachment fault dipping to the north beneath the Gulf of Corinth. This paper describes four north-south structural cross-sections in northern Peloponnesus. Structural and sedimentological field observations show that in the studied area the normal faults of northern Peloponnesus branch at depth on this major low angle north-dipping brittle detachment. The southern part of the detachment and the related normal faults are now inactive. To the north, the active Helike and Aigion normal faults are connected at depth with the seismically active northern part of the detachment beneath the Gulf of Corinth.
\end{abstract}

KEY WORDS: rifting, Corinth Gulf, Peloponnesus, detachment normal fault, Pleistocene

\section{INTRODUCTION : GEODYNAMIC SETTING AND STRUCTURAL FRAME}

Some $130 \mathrm{~km}$ long and 5 to $20 \mathrm{~km}$ wide, the Corinth-Patras rift is the major active transverse structure of the Aegean Arc (Fig. 1). Fault kinematics (Stbrier, 1977), earthquakes focal mechanisms (e.g. Hatzfeld et al., 1996), and satellite geodesy (Clarke et al., 1998) indicate a $\mathrm{N}^{\circ}$ to $20^{\circ} \mathrm{E}$ direction of extension. The extension rate increases toward the west (Le Pichon et al., 1994; Clarke et al., 1998): from 0.5cm/yr near Corinth, it reaches $1.5 \mathrm{~cm} / \mathrm{yr}$ near Aigion. To the west, the active dextral strike-slip Kephalonia fault strikes $\mathrm{N} 20^{\circ} \mathrm{E}$, almost parallel to the extension direction of the rift. Initiating off the Ambracic gulf, it behaves as a transform fault in the convergent front of the Aegean Arc (Le Pichon \& Angelier, 1979).

The northern side of the gulf is a southward flexure of the alpine nappe pile of Central Greece, with some associated south-dipping normal faults. An indented shoreline devoid of recent sediments evidences for the subsidence of this northern coast. In the gulf, seismic reflection profiles confirm this flexure (Brooks \& Ferentinos, 1984).

South of the gulf, northern Peloponnesus presents a 10 to $20 \mathrm{~km}$ wide stripe of faulted synrift sediments (Fig. 3). Near the shore, they build the well-known staircase of stepped marine terraces between Corinth and Xylokastro. The white marls synchronous with these terraces form the younger part (less than $400 \mathrm{kyr}$ ) of the synrift series (Keraudren \& Sorel, 1987). For Armijo et al. (1996), the terraces are uplifted in the footwall of the active normal faults of the rift. Farther south, older synrift deposits are associated with older synsedimentary normal faults (Dufaure, 1975; Stbrier, 1977; Ori, 1989). Structural studies conducted in northern Peloponnesus agree on the fact that these north dipping normal faults have formed the Corinth-Patras rift. But recent seismological studies show that microseismicity of the western gulf defines a low-angle (c.a. $20^{\circ}$ ), shallow north dipping detachment zone (Rietbrock et al., 1996; Rigo et al., 1996) (Fig. 2). The Galaxidi (M=5.9, 1992) and Aigion (M=6.2, 1995) earthquakes (Fig. $1 \& 2$ ) lie in this zone ; their low angle north-dipping nodal planes support the idea of a northdipping detachment fault. A major question is the relationship between this low-angle seismic zone and the steeper normal faults outcropping south of the gulf. Doutsos et al. (1992) have proposed that the normal faults are listric and flatten beneath the Gulf. A recent structural study in northern Peloponnesus noticed that the southernmost fault of the rift is different from the other normal faults (Fig.3): mapping of this long structure shows that is a low-angle detachment fault, on which the steeper normal faults branch. This detachment should connect with the seismically active detachment fault beneath the gulf (Fig 2) (Sorel, 2000). In this paper we describe four north-south structural cross sections in northern Peloponnesus, to illustrate the geometry and the structural evolution of this detachment fault, and of the associated steeper normal faults.

1. Université Paris XI, UMR 8616, Laboratoire tectonique et bassins, bât.504-2, 91405 Orsay Cedex, France. 


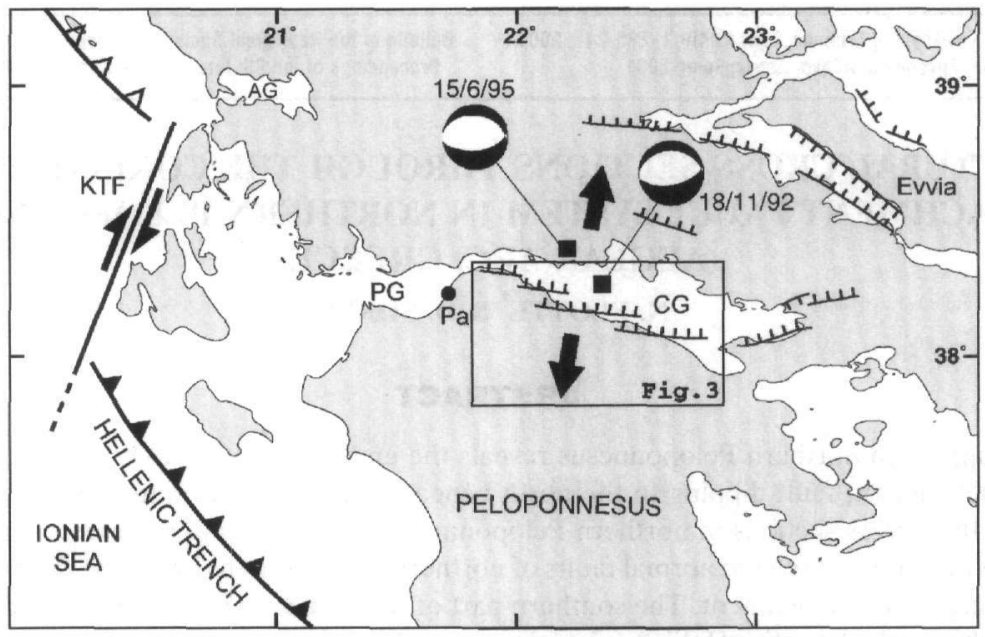

Fig.1-Regional tectonic sketch map. CG, PG: Corinth and Patras Gulfs. KTF: Kephalonia transform fault. Pa: Patras. Focal mechanisms of Aigion (Bernard et al., 1997) and Galaxidi earthquakes (Hatzfeld et al., 1996) are shown. Black arrows: mean direction of extension.

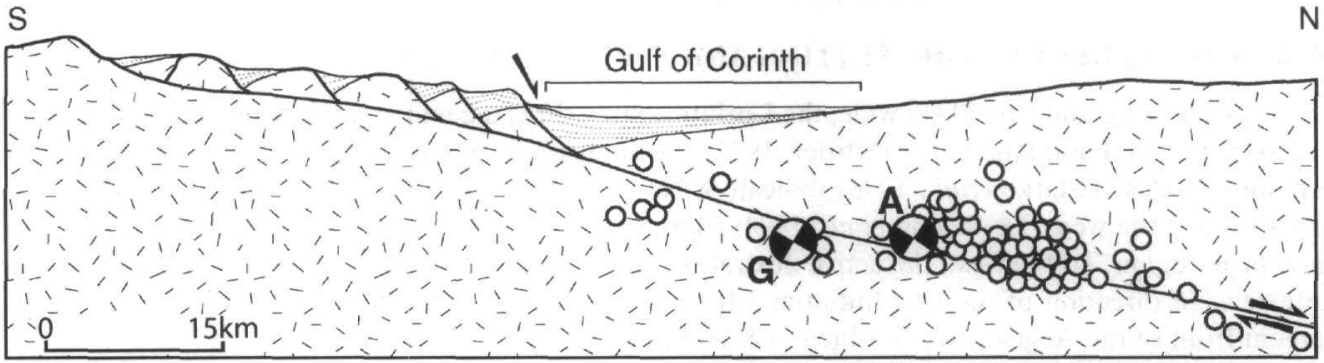

Fig.2-Schematic N-S cross section through northern Peloponnesus and the Gulf of Corinth (after Sorel, 2000). Dashed: alpine basement; points: synrift deposits; white dots: microearthquakes (after Rietbrock et al., 1996); A: Aigion focal mechanism section (Bernard et al., 1997); G: Galaxidi focal mechanism section (Hatzfeld et al., 1996).

\section{CROSS SECTIONS DESCRIPTION:}

Sections 1 and 2 are located in the central part of northern Peloponnesus, in deeply incised valleys (e.g. Krathis, Vouraokos, Kerinitis rivers) due to the strong uplift of the detachment footwall. To the south, sections show the emergence of the detachment fault. To the north, the geometry of synrift sediments (already described for instance by Doutsos et al., 1988), their relations with the normal faults and the shape of rollover structures in their basement allow a reconstruction of the structures at depth, using the classical concepts of fault reconstructions (e.g. Dula, 1991). Sections 3 and 4 are located more to the east where the uplift is lower.

\section{1) The Krathis valley section:}

It extends from the Chelmos Mountains to the gulf at Paralia Platanos (Fig. 4 - 1, location on Fig. 3). The Chelmos massif consists of Mesozoic carbonates of the Gavrovo-Tripolitza (G/T) zone (Dercourt, 1964), dipping about $20^{\circ} \mathrm{S}$. They are overthrust on its southern side by cretaceous limestones of the Pindus ( $\mathrm{Pi}$ ) nappe. G/ T limestones tectonically overlie the epimetamorphic Zaroukla formation (De Wever, 1975; IGME, 1982), also called Phyllite-Quartzite formation. East of the Chelmos ski-centre, above the Krathis valley, Pi limestones overlie G/T limestones by a brecciated tectonic contact trending $\mathrm{N} 100^{\circ}$ and dipping $30^{\circ} \mathrm{N}$. Grooves show a normal sense of slip, and a $\mathrm{N} 10^{\circ}$ extension direction. This contact flattens to the north in the Krathis valley, dipping only $10^{\circ} \mathrm{N}$. It cuts with a low angle through a rollover structure of $\mathrm{Pi}$ and $\mathrm{G} / \mathrm{T}$ limestones, dragged over the Zaroukla formation. The offset of Pi limestones from above the Chelmos is about $4 \mathrm{~km}$. The rollover shows that the contact had a listric shape. Its initial dip was around $50^{\circ}$ at the surface in the Pi nappe, but some $3 \mathrm{~km}$ 


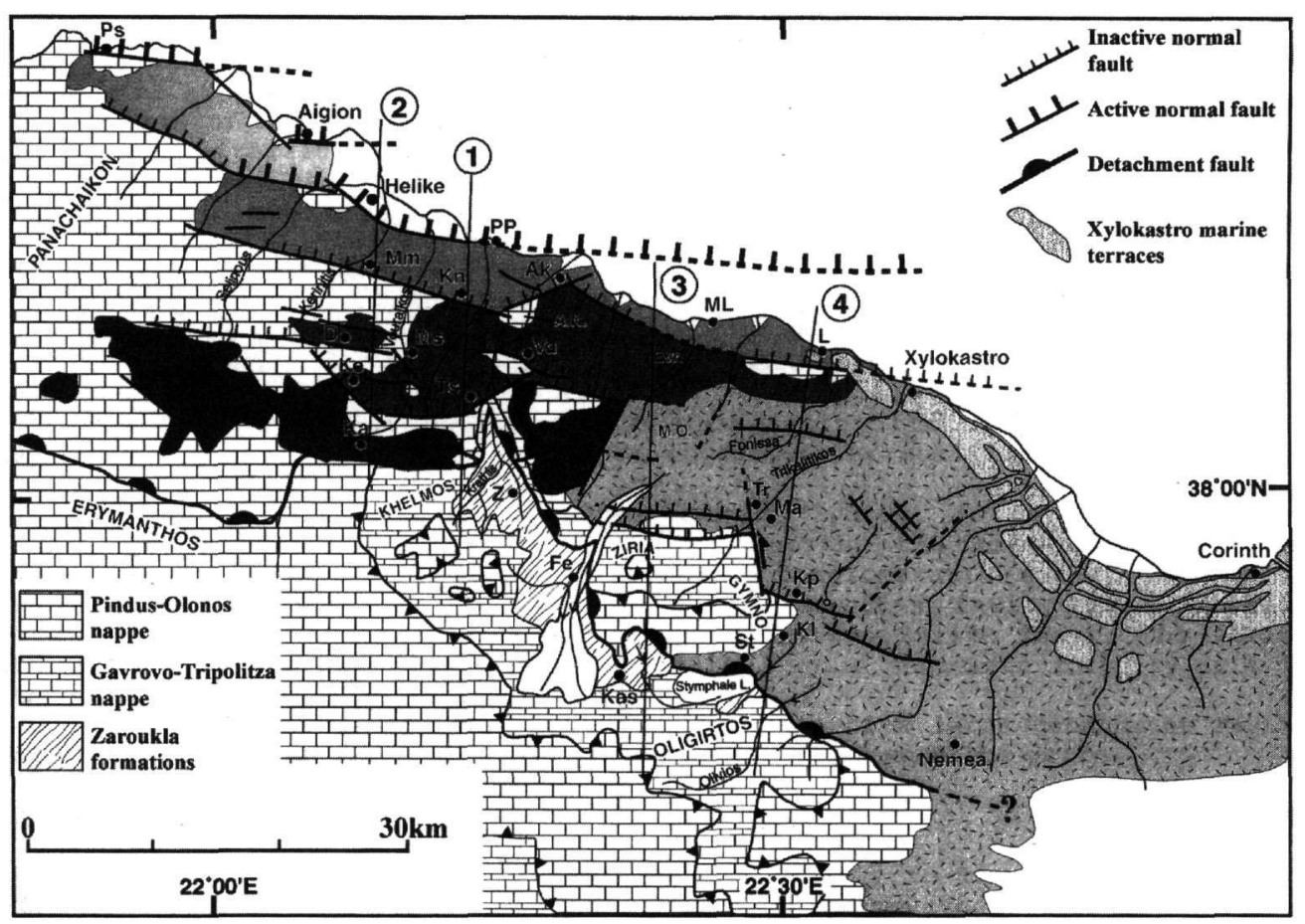

Fig.3-Structural map of the studied area, and locations of the four cross sections of Fig.4. Synrift deposits are in grey; dark grey: older sediments; Light grey: younger sediments; Dashed: undivided age. Dotted grey: marine middle and upper Pleistocene terraces. Ak: Akrata; A.N.: Ayios Nikolaos; D: Doumena; Evr: Evrostina; Fe: Feneos; Ka: Kalavryta; Kas: Kastania; Ke: Kerpini; Kl: Kaliani; Kn: Kernitsa; Kp: Kephalari; L: Loutro; Ma: Manna; Mm: Mamoussia; M.O: Mavron Oros; Ms: Mega Spilaion; PP: Paralia Platanos; St: Stymphalia; Tr: Trikala; Ts: Tsivlos; Va: Valimi; Z: Zaroukla.

deeper it was around $30^{\circ}$ in the $\mathrm{G} / \mathrm{T}$ limestones.

North of the ski centre, this contact is sealed by widespread, strongly cemented and karstified slope breccias made of G/T limestones clasts of the Chelmos. These breccias are now southward backtilted, and dip about $15^{\circ} \mathrm{SW}$. They overlie with a slight discordance fluviatile conglomerates dipping $20^{\circ} \mathrm{S}$. If the conglomerates were deposited flat, the post-detachment southward tilt of the area is of some $20^{\circ}$, and the GT and Pi nappes of the Chelmos were almost horizontal at the initiation of the detachment.

The age of the detachment can be inferred from the slope breccias. Their facies and lithification imply a cold climate. Strongly uplifted, eroded and karstified, they cannot be recent in the Pleistocene. Dufaure (1975) attributes them to a cold time span in the lower Pleistocene (Villafranchian).

To the north, the detachment crosses the Krathis River near the Tsivlos fault (Stolos fault in Sorel, 2000). The Tsivlos fault has controlled the piling of a more than $1 \mathrm{~km}$ thick fan of conglomerates : in its hangingwall, the conglomerates form a divergent infill, and their Pi basement show a rollover anticline dipping up to $30^{\circ} \mathrm{S}$. These geometries implies that the Tsivlos fault branch at depth on the low angle detachment. Slip on the detachment at depth was transferred to the surface by the Tsivlos fault, the southern end of the detachment being locked. The uppermost conglomerates seal the fault on Stolos Mountain.

Farther north, the Ayios Nikolaos massif $(1,000 \mathrm{~m})$ is an other rollover associated with the Valimi fault. To the north, the Kernitsa fault also controlled the piling of a younger deltaic conglomeratic formation (Akrata formation) in its subsiding hanging-wall. Then this fault system locked, probably due to the initiation of the still active Helike fault. The Akrata formation is now uplifted and $7-8^{\circ} \mathrm{S}$ backtilted, while sediments actually pile in the Gulf north of Helike fault.

The Krathis valley section shows the emergence of a large detachment fault, on which steeper normal faults successively branched toward the north. 


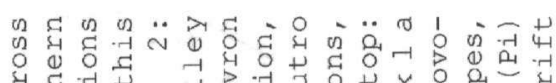

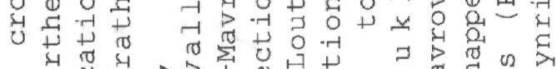

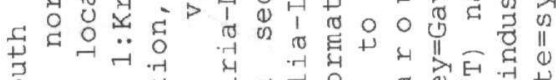

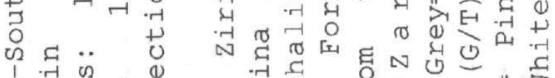

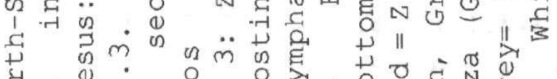

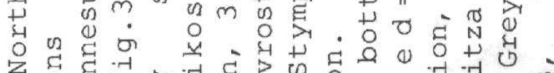

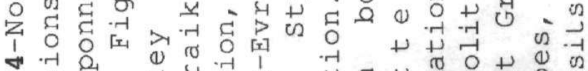

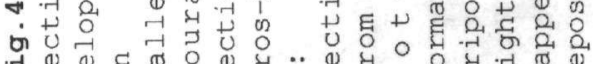

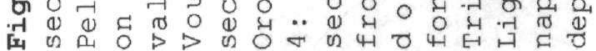

Z

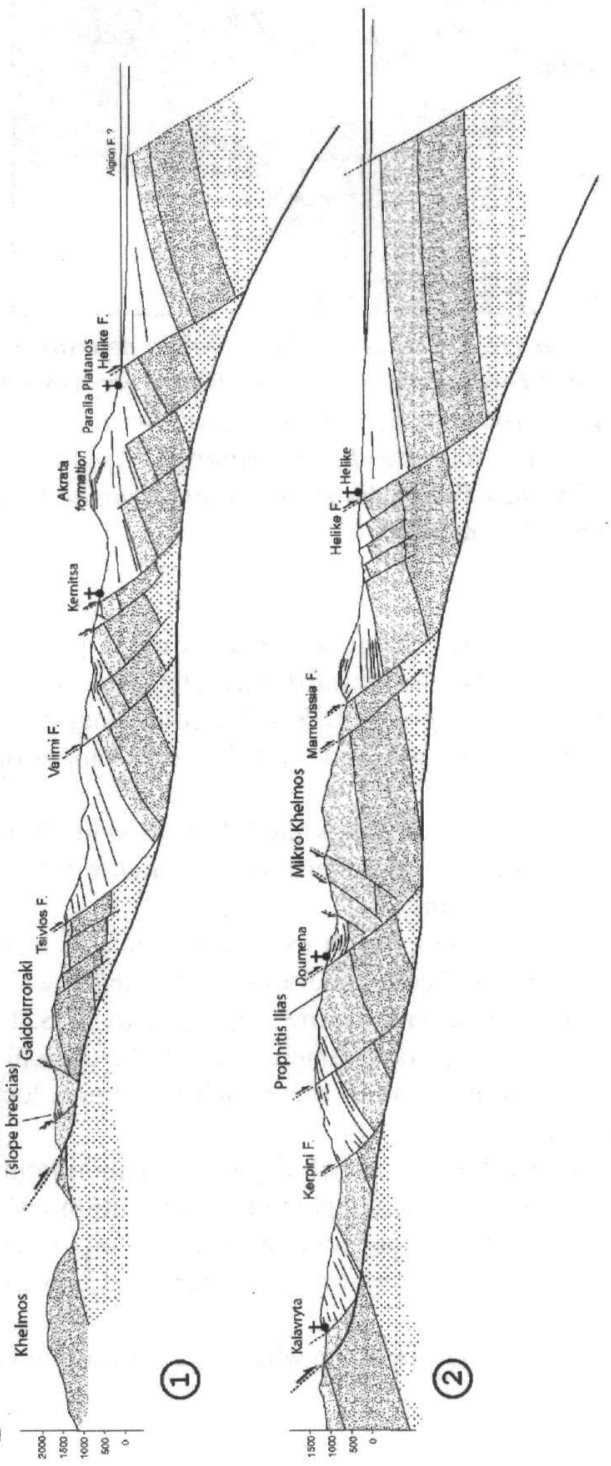

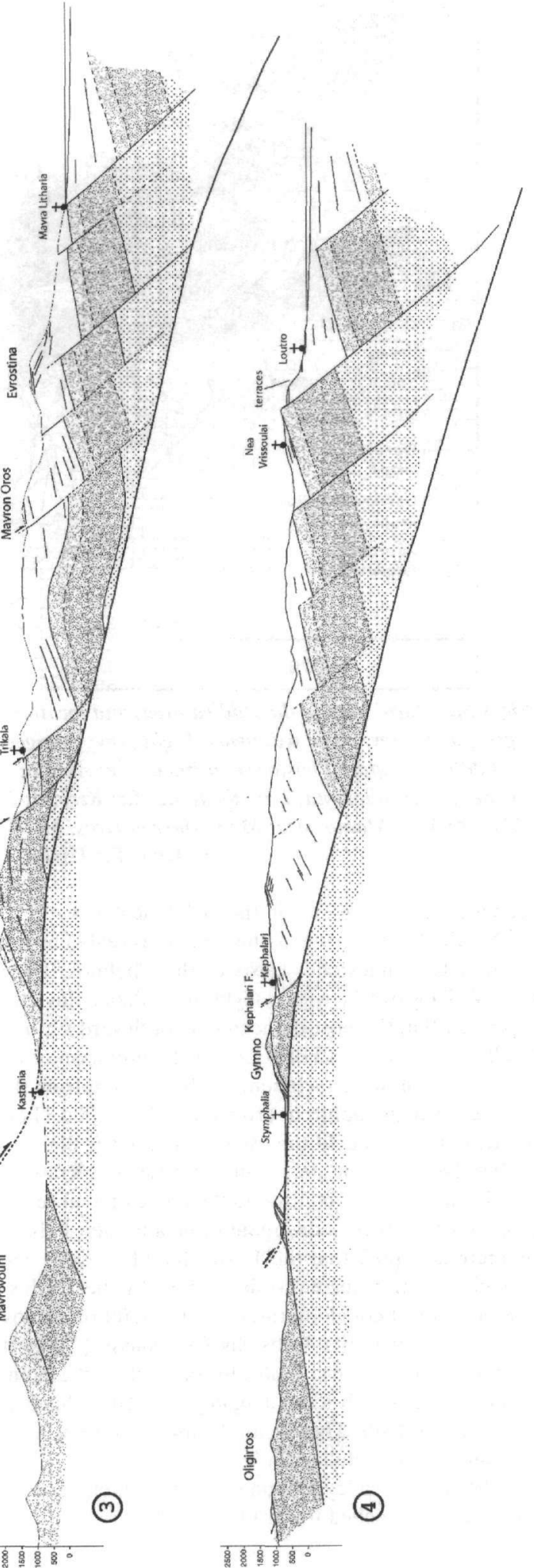

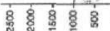




\section{2) The Vouraokos valley section:}

The limestones of Cheimos massif plunge slightly to the west, so that at Kalavryta the detachment brings in contact the Pi limestones with the $20^{\circ}-25^{\circ}$ south-dipping conglomeratic series located north of the Chelmos (Fig. 4-2). Here this series is thicker (more than $1 \mathrm{~km}$ ), which suggests a deepening of the basin floor and of the detachment fault. The first throw on the detachment is about $5 \mathrm{~km}$.

North of Kalavryta, the conglomerates and their Pi basement are folded in a large rollover structure, controlled by the listric shape of the detachment near its emergence. Farther north, the Pi limestones are downthrown by the north-dipping Kerpini normal fault, likely the continuation of the Tsivlos fault. The Kerpini conglomeratic series piled in its hangingwall. The rollover structure of this series implies that sedimentation was controlled by a fault flattening at depth, suggesting the branching of the Kerpini fault on the detachment.

Pi limestones underlying the Kerpini conglomerates crop out farther north. They form to the west the Prophitis Ilias massif, southward tilted south of Doumena village. The prominent north-dipping Doumena normal fault limits the Prophitis Ilias massif from the narrow Doumena graben. This fault downthrows the Kerpini series, which is dragged and dips to the north along the fault. Minor antithetic faults of the northern side of Doumena basin cross the Vouraokos valley. They form the southern limit of the Mikro Chelmos Pi limestone massif. Restoring the culmination of Mikro Chelmos implies a flattening of the detachment at depth. Mega Spilaion monastery is nested in a thick conglomeratic series of the eastern Doumena basin.

$\mathrm{G} / \mathrm{T}$ limestones crop out in the Vouraokos gorge. The next major normal faults to the north, the Mamoussia faults, are the western continuation of the Kernitsa faults. They controlled the deposition of a thick prograding deltaic series, the Akrata formation. When Mamoussia faults were relieved by Helike fault, this series was uplifted and $7-8^{\circ}$ backtilted to the south.

The steep mountain slopes and the straight narrow shoreline near Platanos are determined by the still active Helike fault. To the north, the active Aigion fault may continue offshore, controlling the deposition of the submarine alluvial fan of the Selinous River.

The total throw on the detachment fault along the Vouraokos valley section is of some $16 \mathrm{~km}$.

\section{3) Ziria (Killini Oros)-Mavron Oros-Evrostina section:}

This section begins to the south in the Pi nappe in Oligirtos Mountains (Fig. 4-3). To the north, this nappe overthrusts the G/T limestones of Mavrovouni massif. At Kastania pass the G/T brecciated carbonates dipping $20^{\circ} \mathrm{S}$ overlies the Zaroukla formation. Above Kastania village, detached Pi limestones overlie directly the Zaroukla formation, by an almost flat contact, which continues in the western side of Ziria Mountain (Fig. 2).

The southern side of Ziria Mountain consists of southward backtilted Pi limestones. In the mountain, the flat detachment cuts the c.a. $30^{\circ} \mathrm{S}$ dipping thrust of Pi over the $\mathrm{G} / \mathrm{T}$ limestones. A large rollover flattens the G/ $\mathrm{T}$ limestones in the northern side of Ziria Mountain. The indented northern side of Ziria is determined by several E-W, NNE-SSW and NW-SE striking faults. They downthrow the Pi limestones in a 1,500-1,600m high plateau south of Trikala, partly covered by conglomerates. Trikala faults thicken the series to the north, where it dips $15-20^{\circ} \mathrm{S}$ and contains clayey intercalations.

The section cuts through the western end of the impressive c.a. $15^{\circ} \mathrm{S}$ backtilted conglomeratic delta of Mavron Oros (1759m). Descending from Mavron Oros to the younger Evrostina delta (c.a.1,200m high), a continuous slightly faulted littoral conglomeratic series overlies $5-10^{\circ} \mathrm{S}$ dipping white lacustrine marls of distal facies. Whereas marls are backtilted to the south, conglomerates descend to the north. While the distal marls were uplifted in the footwall of a more northerly-located intrabasinal fault, they were covered by the regressive nearshore conglomerates. North of Evrostina plateau, long north dipping foreset and bottomset beds deposited in deeper water suggest that the active normal fault may have been located north of Evrostina plateau.

At Mavra Litharia, the uplift of Holocene marine shoreline sediments and of the roman harbour of Aegira (ref. in Stiros \& Pirazzoli, 1998) implies that the active fault is located offshore, in the continuation of the Akrata and/or Helike faults.

On this section, Ziria Mountain has been drifted some $6.5 \mathrm{~km}$ to the north by the detachment, which has been later isostatically uplifted, southward backtilted and flattened.

\section{4) Stymphalia-Loutro (Xylokastro) section:}

The section starts in Oligirtos Mountain (Fig 4-4), in south-dipping G/T limestones, overthrust farther south by the Pi nappe. East of Stymphalia Lake, the $20^{\circ} \mathrm{S}$ dipping G/T limestones overlie the Zaroukla formation. 
Both formations are cut by a $15-20^{\circ} \mathrm{N}$ dipping fault.

The hanging-wall of this fault is a conglomeratic series dipping $20-25^{\circ} \mathrm{SSE}$. Its basis, c.a. $40^{\circ} \mathrm{S}$ dipping, discordantly overlies Pi limestones of Gymno Mountain between Stymphalia and Kaliani. The fan shape of this thick series and the occurrence of large GT olistolites in its lower part (Sibrier, 1977), fallen from the Oligirtos GT slopes along the detachment, suggest that this series piled during the activity of the detachment.

The section cuts through the eastern end of Gymno Mountain, where the Pi over GT thrust dips $30^{\circ}-40^{\circ} \mathrm{SE}$. At Kephalari, an important $\mathrm{N} 100^{\circ}$ striking normal fault downthrows the limestones to the north. North of the fault, a syntectonic conglomeratic series shows a $15-20^{\circ} \mathrm{S}$ backtilted Gilbert-type delta. Its foresets, almost horizontal, pass to the north to deeper white marls. Along the northeastern foot of the Gymno, this backtilted series is covered by cemented slope breccias, which seal a N160 striking fault up to Manna.

Farther north, only minor faults seem present in the thick white marls of the Stymphalia and Trikallitikos valleys. Between these valleys, a plateau bears patches of conglomerates which cover $10^{\circ}-15^{\circ}$ southdipping white marls. As in the Mavron Oros-Evrostina area, they may be remnants of regressive nearshore deposits related to the progressive uplift and emersion of the marls, in the footwall of a north-located active fault.

In Trikallitikos (Sitas) valley, the section crosses thick more or less sandy marls. The basal conglomerates of this series discordantly overlie Pi limestones in Fonissa valley, south of Neai Vrissoulai (IGME, 1989). To the north, this series discordantly overlies a c.a. 1,000 m high southward backtilted Pi limestones massif west of Xylokastro. The steep northern slope of this massif shows large exhumed normal fault planes in the limestones. U/Th dating of karstic calcite sealing the fault indicates that it locked before $112 \pm 0.4 \mathrm{kyr}$ (Flottl et al, submitted). North of the Xylokastro-Loutro fault, a lacustrine clayey sandy series with remnants of stepped regressive marine terraces is uplifted and eroded. This uplift implies that the presently active normal fault is located offshore, on the eastern continuation of Akrata or Helike faults.

This section again illustrates the northward migration of the active normal faults and of the rift depocenter.

\section{SYNTHESIS AND IMPLICATIONS ON THE STRUCTURAL EVOLUTION OF THE GULF OF CORINTH:}

The southernmost fault of the Corinth Rift is different from the northern, younger or still active normal faults: it is a much longer structure, about $70 \mathrm{~km}$ from the Panakhaokon to Nemea plain.

- Its emergence dip is only $20^{\circ}-30^{\circ} \mathrm{N}$, and flattens to $0^{\circ}-10^{\circ} \mathrm{N}$ (Krathis valley or Ziria mountain. Its initial dip was about $50^{\circ}$ at the surface, and $30^{\circ}$ at a depth of some $3 \mathrm{~km}$. This value is in the dip range of detachment faults.

- The first slip of this detachment was of c.a. $4 \mathrm{~km}$ in the Chelmos and more than $6 \mathrm{~km}$ beneath the Ziria. This initial slip formed a narrow half graben that collected the first conglomeratic deposits of the proto-rift of Corinth. Slope breccias indicate that this first slip ended during a cold period, that means not older than the early Pleistocene («Villafranchian » of Dufaure, 1975).

- The first slip of this listric detachment formed a wide rollover in the downthrown hanging-wall, and a divergent infill in the syntectonic conglomerates, very spectacular near Stymphalia.

- The general southward tilt of the footwall of the detachment and the flattening of the contact reveal an incipient footwall uplift. This flattening likely caused the lock of the southern part of the detachment, and the formation of new, steeper normal faults to the north. These faults linked the active northern part of the detachment to the surface. As northern Peloponnesus uplifted, the subsident sedimentary basin shifted about $30 \mathrm{~km}$ to the north.

- This mechanism led to the present tectonosedimentary pattern of the rift. Extension, correlative uplift and southward backtilting went on, forming a regional bulge in northern Peloponnesus (the so-called « bourrelet corinthien » of Dufaure (1975), and the southward reversal of rivers (Olivios, Stymphalia and Oligirtos rivers) evidenced by this author.

- North of the active Aigion and Helike faults, the detachment likely continues in the low-angle north-dipping seismically active zone.

Acknowledgments: This research was supported by the CNRS: UMR-8616, and INSU. Thanks to A. Benedicto for his help to balance the cross-sections and to IGME for its help in Greece. 


\section{REFERENCES}

Armijo, R., Meyer, B., King, G.C.P., Rigo, A., Papanastassiou, D., 1996, Quaternary evolution of the Corinth Rift and its implications for the late Cenozoic evolution of the Aegean: Geophy. J. Int., v. 126, p. 11-53.

Bernard, P., Briole, P., Meyer, B., Lyon-Caen, H., Gomez, J.M., Tiberi, C., Berge, C., Cattin, R., Hatzfeld, D., Lachet, C., Lebrun, B., Deschamps, A., Courboulex, F., Larroque, C., Rigo, A., Massonnet, D., Papadimitriou, P., Kassaras, J., Diagourtas, D., Makropoulos, 1997, The Ms=6.2, June 15, 1995 Aigion earthquake (Greece): evidence for low angle normal faulting in the Corinth rift: Journal of Seismology, v. 1, p. 131-150.

Brooks, M., and Ferentinos, G., 1984, Tectonics and sedimentation in the Gulf of Corinth and the Zakynthos and Kefallinia Channels, western Greece: Tectonophysics, v. 101, p. 25-54.

Clarke, P.J., Davies, R.R., England, P.C., Parsons, B., Billiris, H., Paradissis, D., Veis, G., Cross, P.A., Denys, P.H., Ashkenazi, V., Bingley, R., Kahle, H.G., Muller, M.V., Briole, P., 1998, Crustal strain in central Greece from repeated GPS measurements in the interval 1989-1997: Geophys. J. Int., v. 135, p. 195-214.

Dercourt, J., 1964, Contribution à l'étude géologique du secteur du Péloponnèse septentrional: Thèse d'Etat, Paris, Faculté des Sciences de l'Université de Paris.

De Wever, P., 1975, Etude géologique des séries apparaissant en fenêtre sous l'allochtone pindique (séries de Tripolitza et séries épimétamorphiques de Zaroukla). Péloponnèse septentrional, Grèce: Lille, Université des Sciences et Techniques de Lille.

Doutsos, T., Kontopoulos, N. and Poulimenos, G., 1988, The Corinth-Patras rift as the initial stage of continental fragmentation behind an active island arc (Greece) : Basin Res., 1, 177-190.

Doutsos, T., and Poulimenos, G., 1992, Geometry and kinematics of active faults and their seismotectonic significance in the western Corinth - Patras rift (Greece): Journal of Structural Geology, v. 14, p. 689-699.

Dufaure, J.J., 1975, Le relief du Péloponnèse: Paris, Université Paris IV.

Dula, W.F., 1991, Geometric models of listric normal faults and rollovers folds: A.A.P.G. Bull., 75, 10, 16091625.

Flotté, N., Plagnes, V., Sorel, D., Benedicto, A., 2001, Attempt to date Pleistocene normal faults of the CorinthPatras Rift (Greece) by U/Th method, and tectonic implications: Geophysical Research Letters, submitted.

Hatzfeld, D., Kementzetzidou, V., Karakostas, V., Ziazia, M., Nothard, S., Diagourtas, D., Deschamps, A., Karakaisis, G., Papadimitriou, P., Scordilis, M., Smith, R., Voulgaris, N., Kiratzi, S., Makropoulos, K., Bouin, M.P., Bernard, P., 1996, The Galaxidi Earthquake of the 18 November 1992: A Possible Asperity within the Normal Fault System of the Gulf of Corinth (Greece): Bulletin of the Seismological Society of America, v. 86, p. 1987-1991.

IGME, 1982, 1/50.000 geological map of Greece, Khandila sheet.

IGME, 1989, 1/50.000 geological map of Greece, Xylokastro sheet.

Keraudren, B., and Sorel, D., 1987, The terraces of Corinth (Greece) - a detailed record of eustatic sea - level variations during the last 500,000 years: Marine Geology, v. 77, p. 99-1070.

Le Pichon, X., Angelier, J., 1979, The Hellenic arc and trench system: a key to neotectonic evolution of the eastern Mediterranean area: Tectonophysics, v. 60, p. 1-42.

Le Pichon, X., Chamot-Rooke, N., Noomen, R., and Veis, G., 1994, Kinematics of Anatolia-Aegean with respect to stable Europe based on a combination of SLR and geodetic measurements over 80 years: C. R. Ac. Sci. Paris, Série-II, v. 318, p. 1387-1400.

Ori, G.G., 1989, Geologic history of the extensional basin of the Gulf of Corinth (?Miocene-Pleistocene), Greece: Geology, v. 17, p. 918-921.

Rietbrock, A., Tiberi, C., Scherbaum, F., and Lyon-Caen, H., 1996, Seismic slip on a low angle normal fault in the gulf of Corinth : Evidence from high-resolution cluster analysis of microearthquakes: Geophysical Research Letters, v. 23, p. 1817-1820.

Rigo, A., Lyon-Caen, H., Armijo, R., Deschamps, A., Hatzfeld, D., Makropoulos, K., Papadimitriou, P., and Kassaras, I., 1996, A microseismic study in the western part of the Gulf of Corinth (Greece): implications for large-scale normal faulting mechanisms: Geophysical Journal International, v. 126, p. 663-688.

Sébrier, M., 1977, Tectonique récente d'une transversale à l'arc égéen. Le Golfe de Corinthe et ses régions périphériques: Thèse 3eme cycle, Paris, Univ. Paris XI-Orsay.

Sorel, D., 2000, A Pleistocene and still-active detachment fault and the origin of the Corinth - Patras rift, Greece: Geology, v. 28, p. 83-86.

Stiros, S.C. and Pirazzoli P.A., 1998, Field trip guide, Joint Meeting on Rapid coastal changes in the late Quaternary: processes, causes, modelling, impact on coastal zones, Greece. 